\title{
Analisis Kesehatan Kerja Pembantu Rumah Tangga di Surabaya
}

Tri Rini Puji Lestari*

\begin{abstract}
Abstrak
Perempuan pembantu rumah tangga (PRT) dipandang sebagai potret buram perempuan saat ini. Keberadaan PRT diselimuti oleh berbagai persoalan struktural seperti kemiskinan, diskriminasi, ideologi patriarki, feodalisme dan klas. Penelitian ini bertujuan mengetahui kondisi kesehatan kerja PRT di Surabaya. Metode penelitian yang digunakan adalah metode kualitatif dengan melakukan wawancara mendalam kepada informan kunci. Hasil penelitian menunjukkan bahwa kapasitas kerja, beban kerja, dan beban tambahan yang diterima PRT menjadikan PRT disebut sebagai "pekerja yang serba bukan" karena posisi "marginal" dari status sekaligus posisi PRT. Selain itu, sampai saat in, di Surabaya PRT belum mendapat perlindungan hukum. Sebagai gambaran bahwa pekerjaan PRT masih belum dianggap sebagai profesi yang layak yang diatus secara khusus sebagaimana a profesi-profesi yang llain.

Kata kunci: Kesehatan kerja, pembantu rumah tangga

Abstract

Housemaid (PRT) has been viewed as dark portrait of woman condition at the present. Structural problems such as poverty, discrimination, patriarchic ideology, feudalism and class conflict were surrounded PRT problem. The purpose of this study was to understand the health condition of PRT in Surabaya. The method used in this study was qualitative method by conducting in-depth interview to key informants. Result of this study indicates that capacities of work, work load, and additional burden of PRT its make PRT conceived of "worker whose none at all " because of "marginal" position and status of PRT. Besides, there is no law protection for PRT in Surabaya and PRT job has not been viewed as a proper employment.
\end{abstract}

Keywords: Health work, housemaid 
Jumlah penduduk yang hidup dibawah garis kemiskinan saat ini lebih dari 30 juta orang. Perekonomian nasional yang memburuk mendorong orang untuk mencari kerja dalam kondisi dan situasi kerja yang kurang menguntungkan. ${ }^{1}$ Saat ini, di Indonesia diperkirakan sekitar 2,5 juta orang bekerja sebagai Pekerja Rumah Tangga dan sekitar 90\% di antaranya adalah perempuan. Pekerja rumah tangga atau sering disebut sebagai pembantu rumah tangga (PRT) baik yang bekerja di Indonesia maupun di luar negeri, termasuk dalam kategori pekerja yang dipekerjakan oleh individu ataupun perusahaan. ${ }^{1}$

Sejak berabad silam, PRT telah menjadi bagian dari budaya dan kehidupan masyarakat di Indonesia. Tidak berlebihan jika dinyatakan bahwa mereka merupakan bagian dari suatu proses perkembangan masyarakat yang entah kapan bermula. Lapangan pekerjaan yang semakin menyempit akibat teknologi masuk pedesaan, menyebabkan banyak pekerjaan yang sebelumnya dilakukan oleh perempuan desa diambil oleh mesin. Padahal, desakan ekonomi semakin terasa berat, yang memaksa mereka terpaksa berimigrasi ke kota mencari pekerjaan. Akibatnya, terjadilah arus deras para perempuan desa yang pergi ke kota untuk bekerja menjadi PRT.

Di Indonesia dan di luar negeri, pekerja rumah tangga berkontribusi sangat besar pada kemajuan dan kesejahteraan keluarga. Banyak pekerjaan rumah tangga yang diambil alih memberi peluang pada keluarga majikan untuk melakukan pekerjaan lain yang produktif. Tidak jarang perusahaan rumah tangga berkembang dan mengalami kemajuan yang pesat dengan bantuan PRT. Banyak ibu rumah tangga yang berhasil menyelenggarakan usaha- usaha tanpa harus meninggalkan rumah tangga dengan bantuan PRT. Banyak anak-anak yang berhasil menyelesaikan pendidikan karena terbebas dari beban pekerjaan rumah tangga berkat bantuan PRT. Banyak bayi yang kedua orang tuanya bekerja terawat dengan baik penuh cinta dan kasih sayang lewat tangan pembantu.

Seorang pembantu rumah tangga yang umumnya perempuan bekerja di dalam sebuah keluarga, bukan hanya membantu tetapi juga menawarkan jasa melakukan pekerjaan rumah tangga majikan. Demikian juga sebaliknya pengguna jasa mempekerjakan PRT untuk menyelesaikan pekerjaan kerumahtanggaan, bukan sekedar membantu. Dengan demikian para pekerja rumahtangga tersebut memerlukan keterampilan khusus tentang berbagai pekerjaan rumah tangga di rumah majikan mereka. Padahal, para pekerja tersebut umumnya berasal dari rumah tangga di desa yang mempunyi fasilitas yang sangat sederhana yang jauh berbeda dengan rumah majikan mereka. Tentu saja ada kesenjangan yang sangat besar antara keterampilan yang di- miliki dengan jasa ideal yang dibutuhkan. Selain itu, ada kebutuhan mendesak yang perlu dipenuhi oleh para pekerja PRT yang berasal dari keluarga miskin. Misalnya, dalam situasi paceklik di daerah pertanian, bekerja pada keluarga yang lebih kaya yang bermukim di sekitar tempat tinggal mereka. Para PRT membawa anak mereka yang masih kecil. Di samping dapat mengawasi anak mereka selama mereka bekerja, mereka juga dapat memperoleh makanan dan minuman bersama, sehingga akan lebih meringankan beban ekonomi keluarga. ${ }^{2}$

Sampai kini, peran perempuan sebagai PRT tidak mudah dihapuskan, disamping karena kesulitan dalam mengganti peran mereka, juga karena lowongan kerja lain masih sangat terbatas. Kebanyakan mereka tidak memenuhi standar kualifikasi pendidikan yang dibutuhkan. Di banyak wilayah, sebagian besar PRT tersebut berasal dari pedesaan. Lapangan kerja yang semakin terbatas membuat mereka harus mencari kerja di wilayah lain yang jauh rumah tempat tinggal mereka. Mereka bekerja di kota-kota besar yang umumnya belum pernah mereka kunjungi, pada keluarga yang sebelumnya tidak mereka kenal. Bahkan dalam situasi yang sebelumnya tidak pernah terbayangkan. Di sinilah dimensi baru pekerjaan rumah tangga bermula. Hubungan yang semula bersifat kekerabatan menjadi semakin pudar dan mungkin juga menjadi hilang. Selanjutnya, terjadilah hubungan antara seorang majikan dan orang upahan.

Meskipun demikian, PRT belum diakui sebagai pekerja formal yang mendapat perlindungan dan hak-hak yang layak sebagaimana lazimnya seorang pekerja. Hukum dan peraturan yang berlaku masih sangat diskriminataif dan tidak berpihak pada PRT. Mereka tergolong pekerja informal yang termargimalisasikan dan sering mendapat perlakuan kasar dan semena-mena. Mereka sibuk dalam hiruk-pikuk kegiatan rutin sehari-hari, tersembunyi dalam lingkungan rumah tangga yang hening dan tertutup, dan terisolasi dari tetangga dan orang luar.

Para PRT tersebut bukan saja memerlukan dukungan untuk meningkatkan kapasitas kerja, tetapi juga memerlukan perlindungan dari beban kerja berlebihan, penindasan dan ketidakadilan. Kapasitas kerja adalah kemampuan seseorang menyelesaikan pekerjaannya dalam suatu medan kerja tertentu. Kapasitas kerja mencakup tenaga yang diperoleh dari gizi yang baik, kondisi badan yang sehat dan kemampuan individu yang meliputi keterampilan dan tingkat pendidikan. Beban kerja adalah pekerjaan yang menjadi tanggung jawab seorang pekerja yang pada pekerja sektor informal seperti PRT memerlukan kapasitas fisik yang prima. Beban tambahan adalah keadaan lingkungan pekerjaan yang berpengaruh secara langsung atau tidak langsung terhadap kinerja yang dihasilkan. Seperti keserasian dan kelengkapan alat yang digunakan, 
suhu udara panas, upah terlalu rendah, sosialisasi dan rekreasi. ${ }^{3}$

Bagaikan potret buram perempuan Indonesia saat ini, mereka merupakan bagian masyarakat yang tidak berdaya di tengah modernisasi dan kapitalisme yang berkembang pesat. Perempuan PRT, meningatkan kita pada perbudakan yang sejak lama ditentang dan dihapuskan. Mereka adalah pekerja keras tanpa jam kerja, gaji kecil dan sering menjadi korban penindasan dan kesemena-menaan. Sehingga tidak mengherankan jika perempuan PRT tersebut menghadapi banyak masalah, seperti pelecehan, kekerasan fisik, psikis, seksual ataupun penelantaran yang lebih dikenal sebagai Kekerasan Dalam Rumah Tangga (KDRT). ${ }^{2}$ Sangat jarang PRT yang mampu melawan KDRT yang mereka hadapi. Penindasan hak-hak PRT sebagai pekerja, seperti kesemena-menaan, perlakuan yang tidak manusiawi merupakan manifestasi dari praktek perbudakan domestik (domestic slavery). Dalam praktek ini, terjadi eksploitasi dan pemaksaan kerja terhadap PRT.

Lapangan kerja yang semakin sempit membuat pekerja rumah tangga tidak lagi didominasi kaum perempuan, tetapi semakin banyak dimasuki laki-laki.Terlepas dari jenis kelamin tersebut, secara keseluruhan dari aspek hukum, sosial dan kesehatan, PRT kurang mendapat penghargaan dan perlindungan yang layak. Hal ini disebabkan oleh ketimpangan kelas dan relasi kekuasaan. Penelitian yang dilakukan beberapa Lembaga Swadaya Masyarakat (LSM) pada tahun 2003 menemukan bahwa jika sakit sebagian besar PRT akan minum obat dari majikan, beli sendiri ke warung, beristirahat, dan menangis. ${ }^{2}$ Hal tersebut merupakan perlindungan kesehatan kerja bagi PRT yang kurang. Untuk itu penulis tertarik untuk mengetahui lebih lanjut bagaimana kondisi kesehatan kerja PRT dengan mengambil studi kasus di Surabaya. Penelitian ini diharapkan dapat memberikan informasi tentang kondisi kesehatan kerja pada PRT di Surabaya.

\section{Metode}

Penelitian ini menggunakan metode kualitatif dengan menggunakan data primer yang di dapat dengan melakukan wawancara mendalam pada informan kunci yaitu Pejabat di Dinas Tenaga Kerja Provinsi Surabaya dan LSM Kelompok Perempuan Pro Demokrasi (KPPD). Subyek penelitian adalah PRT yang bekerja di perumahan wilayah Surabaya. Analisis temuan penelitian didukung dengan data sekunder dari BPS Surabaya, surat kabar dan bahan-bahan kepustakaan lainnya.

\section{Hasil}

\section{Gambaran Umum}

Secara umum tidak ada data resmi yang menje- laskan jumlah PRT di Surabaya baik oleh Pemerintah maupun LSM yang melakukan pendampingan. Dilihat dari daerah asalnya, sebagian besar PRT berasal dari berbagai kota di Jawa Timur yang antara lain meliputi Kabupaten Bojonegoro, Blitar, Nganjuk, Ponorogo, dan Kediri. Kota-kota tersebut merupakan daerah pedesaan dengan produksi pertanian yang relatif rendah. Selain itu, meskipun tidak banyak, ditemukan PRT yang berasal dari luar Jawa Timur seperti Solo dan Rembang (Jawa Tengah), Kendari (Sulawesi Tenggara), Lampung (Sumatera Selatan), Kupang (NTT) dan Sumbawa (NTB). Kehadiran PRT dari luar Surabaya ini merupakan gejala umum yang menjadikan faktor ekonomi sebagai alasan utama calon PRT datang ke Surabaya.

Di daerah asal dirasakan sudah mulai sulit mencari pekerjaan karena sumber daya yang lemah dan produktifitas yang menurun. Para pekerja mengetahui bahwa kota Surabaya menjanjikan lowongan pekerjaan karena merupakan area pembangunan yang mayoritas hanya tefokus di kota berdampak pada sirkulasi uang dan jumlah lapangan kerja lebih banyak dibandingkan daerah asal PRT itu sendiri. Dengan demikian, Kota Surabaya menjadi salah satu kota tujuan pencari kerja dengan asumsi banyak keluarga yang bekerja di sektor publik membutuhkan orang lain untuk pekerjaan domestik, terutama untuk golongan keluarga menengah ke atas. Disamping itu, banyaknya fasilitas umum dan kemudahan aksesibilitas menjadi salah satu faktor pendorong kota Surabaya menjadi salah satu kota tujuan. PRT datang ke Surabaya umumnya selalu bersama pihak lain yang menjadi perantara sudah dikenal oleh calon PRT seperti saudara, teman, tetangga, orang tua, dan lain-lain dan sebelumnya pernah bekerja di Surabaya. Namun, juga PRT yang dibawa calo, agen pengerah PRT, atau majikan yang dengan sengaja pulang ke daerah asal untuk mencari PRT.

Para perantara tersebut memberi informasi tentang jenis pekerjaan, gaji dan fasilitas pekerjaan meskipun pada kenyataannya ada yang tidak sesuai dengan apa yang diinformasikan, bagi PRT yang pekerjaannya tidak sesuai dengan tawaran sebelumnya, menyatakan bahwa pekerjaaan yang dijanjikan padanya adalah sebagai "kacung" atau bekerja sebagai pelayan di toko. Meski ada yang mendapakan informasi tentang pekerjaannya, namun ternyata masih banyak yang tidak mendapatkan keterangan apapun tentang pekerjaan yang akan dijalaninya. Biasanya calon PRT ini hanya diajak datang ke kota Surabaya oleh perantara, dan asal bisa mendapatkan pekerjaan. Berdasarkan pola relasi antara PRT dan perantara, menunjukkan bahwa konsep sentimen of community dan sentimen of locality yang menggambarkan adanya ikatan emosional personal yang kuat antara PRT dengan kerabatnya oleh karenanya perasaan 
bersama tentang identitas kelompok sosialnya dan kecintaan terhadap lokasi geografis/desa mereka, tampak lebih kuat dibandingkan dengan pola relasi kontraktual yang dikembangkan oleh agen penyalur tenaga PRT. Keluarga yang memerlukan PRT mayoritas adalah keluarga yang berasal dari kalangan menengah atas, rata-rata bekerja/beraktifitas di luar rumah, masih mempunyai anak kecil, atau ada anggota keluarga yang sudah lansia.

\section{Kondisi Kesehatan Kerja \\ Kapasitas Kerja}

Sebagian besar PRT berjenis kelamin perempuan dan berusia antara 12 tahun sampai 35 tahun. Namun, PRT anak (berusia $<18$ tahun) banyak diminati oleh keluarga pengguna jasa karena PRT anak dibayar lebih murah, penurut, lugu dan tidak banyak membantah. sebagaian besar PRT pernah mengikuti pendidikan formal (tamat sekolah dan tidak tamat) mulai dari sekolah dasar (SD), sekolah lanjutan tinggkat pertama (SLTP) sampai sekolah lanjutan tingkat atas (SLTA). Namun, rata-rata PRT hanya mampu menempuh pendidikan SLTP sebagai pendidikan formal yang tertinggi dan tidak tamat sekolah lanjut tingkat atas. Selain itu, ada juga beberapa PRT yang sempat mengenyam pendidikan informal seperti kursus menjahit, les komputer, les matematika dan pondok pesantren.

Umumnya PRT, tersebut mengalami sakit maag, flu, sakit perut, sakit kepala, panas, batuk, gejala typhus, dan pegal-pegal. Untuk mengobati sakit tersebut, PRT sering hanya mengobati dengan memakai jamu atau obat yang dibeli dari warung/obat eceran yang dijual bebas. Hanya sedikit yang dibawa ke dokter, puskesmas, rumah sakit atau klinik. Sebagian besar PRT mendapat makan 3 kali sehari dan memakan makanan yang dimakan majikan mereka. Jika berbeda, biasanya karena beberapa alasan seperti PRT memasak sendiri karena tidak cocok dengan menu yang dimakan majikan, majikan makan di luar rumah, masakan majikan mengandung babi dan dianggap berbeda status. Namun, sebagaian besar PRT mendapat kesempatan melaksanakan ibadah yang sesuai dengan agamanya.

\section{Beban Kerja}

Setiap hari, PRT mulai bekerja pada pagi hari (sekitar jam 400 wib) hingga sore atau malam hari. Jam kerja tersebut tidak berbeda pada akhir pekan sabtu dan minggu. Sebagian besar dari PRT menyatakan tidak mempunyai hari libur (mingguan/bulanan). Namun mereka mendapatkan libur setahun sekali pada saat hari raya. Kesempatan untuk berekreasi biasanya dilakukan dengan menonton TV, nonton bioskop/orkes, baca majalah/koran/tabloit, jalan-jalan, berkunjung ke rumah teman atau ke pasar. Secara garis besar pekerjaan yang sering dilakukan oleh PRT dapat digolongkan sebagai berikut: (1) Pekerjaan dapur: memasak, menyiapkan makanan dan mencuci perlengkapan makan dan masak serta berbelanja, terkadang berbelanja dilakukan oleh majikan. (2) Perawatan rumah / kebun / halaman antara lain: menyapu, mengepel, merapikan kamar, membersihkan kamar mandi, membersihkan jendela/langit-langit, menyiram tanaman, memotong/mencabut rumput dan merawat tanaman. (3) Perawatan pakaian: mencuci dan menyetrika. (4) Mengasuh anak: memandikan, menyuapi makanan, mengantar anak majikan ke sekolah dan menjaga anak majikan. (5) Perawatan hewan peliharaan: memandikan dan memberi makan hewan peliharaan. (6) Mencuci mobil atau motor. (7) Menjaga keamanan rumah seperti membuka dan menutup pagar atau gerbang rumah. (8) Membersihkan kantor majikan, dipekerjakan di toko atau diperbantukan ke kerabat majikan. (9) Memandikan, menjaga dan melayani lansia orang tua majikan. Untuk PRT part time, mereka datang pada pagi hari khusus untuk melakukan pekerjaan tertentu seperti mencuci pakaian dan menyetrika. Pekerjaan rumah tangga yang lain biasanya dikerjakan oleh majikan perempuan yang tidak bekerja di sektor publik.

\section{Beban Tambahan}

Di Surabaya, PRT yang tidak tinggal dengan majikannya sangat jarang dijumpai. Hal tersebut umumnya disebabkan oleh PRT berasal dari luar kota Surabaya. PRT yang tidak tinggal dengan majikan, biasanya adalah tetangga sekitar yang umumnya bekerja secara paruh waktu. PRT yang yang tinggal dengan majikan mereka yang mempunyai fasilitas kamar tidur sendiri sangat sedikit. Kebanyakan mereka tinggal sekamar dengan PRT lainnya, dengan anak majikan atau dengan sopir. PRT yang bekerja pada majikan tegolong kelompok atas/elit dan menengah, biasanya peralatan kerja yang tersedia sama. antara lain: mesin cuci, kompor gas, microwave, oven, setrika listrik, mesin pemotong rumput dan blender. Perlengkapan lain seperti alat pel, vacuum cleaner dan rice cooker juga tersedia, ditambah dengan gunting rumput dan ember untuk menimba air. Biasanya, PRT terlebih dahulu diberitahu oleh majikan atau PRT yang lebih senior tentang cara mengoperasikan alat-alat tersebut, meskipun ada juga yang tidak diberitahu cara menggunakan perlengkapan tersebut.

PRT terkadang mengalami kecelakaan ketika bekerja seperti terpeleset, tersayat pisau, tersengat arus listrik atau jatuh dari tangga, dan lain-lain, akibat lingkungan kerja yang tidak mendukung. Selain itu PRT juga sering mengalami kekerasan dari majikannya (KDRT) yang dapat berupa kekerasan fisik, psikis dan seksual. Kekerasan fisik berupa pemukulan, tidak diberi makan, 
penyekapan, penganiayaan, disiram air panas, hingga menyebabkan kematian PRT. Kekerasan psikis yang sering terjadi adalah dimarahi dan dicaci maki jika melakukan kesalahan. Kekerasan seksual yang sering terjadi berupa pelecehan seksual mulai dari pencabulan hingga perkosaan. PRT paling sering mendapat serangan seksual berupa perkosaan dengan pelaku majikan lakilaki, anak majikan, saudara majikan yang lebih berkuasa dari PRT. Kasus perkosaan terhadap PRT tersebut sering tidak ditindaklanjuti ke pengadilan. Biasanya kasus berhenti sebatas laporan ke kepolisian setempat akibat intervensi pihak keluarga majikan berdamai dengan korban.

Terhadap jasa pekerjaan rumah tangga tersebut para PRT mendapat imbalan berupa gaji yang disepakati ketika mulai bekerja. Secara umum, upah PRT di Surabaya berkisar Rp 200.000 - Rp 300.000 yang biasanya diterima sendiri dan digunakan untuk mencukupi kebutuhan, dikirim ke keluarga di desa dan ditabung. Tidak jarang, gaji PRT sering tidak dibayar oleh majikan dengan berbagai dalih seperti ditabung oleh majikan agar uang tidak habis atau dibayarkan saat PRT akan pulang. PRT juga pernah diberi hadiah, tips atau bonus dari majikan mereka, terutama saat hari raya lebaran. Hadiah tersebut paling banyak dalam bentuk uang, makanan dan kue, pakaian serta barang elektronik. Umumnya PRT menyatakan masih bisa berhubungan dengan keluarga di daerah asal melalui telpon atau surat. PRT masih diperbolehkan pulang untuk menjenguk keluarga atau dijenguk oleh anggota keluarga di tempat kerja, atau mengobrol dengan sesama PRT dalam satu kompleks. Pada beberapa kasus ditemui juga PRT yang mengalami penyekapan dan penutupan seluruh akses.

\section{Kebijakan Pemerintah}

Sampai saat ini, Indonesia belum mempunyai kebijakan khusus untuk PRT, bahkan undang-undang perburuhan belum mencakup PRT. Namun, beberapa undang-undang nasional lain memberikan perlindungan untuk bidang tertentu, meskipun dengan cara yang terpisah-pisah dan terbatas, antara lain meliputi: (1) Undang-undang nomor 23 tahun 2004 tentang penghapusan kekerasan di rumah tangga. (2) Undang-undang nomor 23 tahun 2002 tentang perlindungan anak; (3) Undang-undang nomor 39 tahun 1999 tentang Hak Asasi Manusia; dan lain-lain. ${ }^{4}$ Selain itu, Indonesia juga mengeluarkan undang-undang untuk mengesahkan beberapa norma hukum internasional terkait, seperti: (1) Deklarasi universal Hak Asasi Manusia; (2) Kovenan tentang penghapusan segala bentuk diskriminasi terhadap perempuan; Konvensi tentang Hak-hak Anak; dan lain-lain. ${ }^{4}$ Sampai saat ini di Surabaya belum ada perlindungan hukum dan organisasi para PRT yang berfungsi sebagai wadah untuk menyalurkan hak-hak mereka sebagai perempuan, pekerja, dan warga negara. Hal ini berarti tidak ada perlindungan hukum yang menjamin penegakan hak PRT sebagai manusia, perempuan dan buruh.

Anggapan bahwa PRT adalah pekerja rendah dan sebagian masyarakat menempatkan sebagai wilayah privat, sering menjadi alasan ketiadaan perlindungan (intervensi yuridis). Terkait aspek yuridis dan sosial, pola dan kondisi hubungan PRT dengan majikan tergantung pada kebaikan hati majikan yang tidak ada batas dan bersifat relatif. Hal ini tentu bertentangan dengan prinsip hak asasi manusia yang kemerdekaan mereka ditentukan oleh orang lain. Bukan berdasar jaminan hak asasi yang melekat padanya. ${ }^{2}$

\section{Pembahasan \\ Gambaran Umum}

Bahwa sebagian besar PRT di Surabaya berjenis kelamin perempuan, bukan kebetulan, tetapi karena mereka hidup dalam masyarakat dengan sistem budaya patriarki yang menjeniskan pekerjaan dan pembagian kerja, sehingga lebih banyak perempuan bekerja di sektor domistik daripada laki-laki. PRT umumnya berasal dari daerah pedesaan dengan produksi pertanian relatif minus. Dikaitkan dengan proporsi perempuan yang lebih banyak menjadi PRT dapat dikatakan bahwa korban utama kemiskinan adalah perempuan. Namun, hal tersebut bukan merupakan ciri khas PRT perempuan, tetapi merupakan gejala umum pada masyarakat yang didomonasi oleh budaya patriaki.

Kemiskinan yang melanda keluarga PRT umumnya berkaitan dengan lemahnya sumber daya produksi di daerahnya. Itulah sebabnya meskipun umumnya mereka memiliki rumah sendiri, mereka tetap harus berjuang mencari lapangan kerja keluar dari daerahnya, karena tanah disekitarnya kurang produktif. Gejala ini sangat berhubungan dengan pusat pembangunan di kota-kota besar yang berdampak pada perputaran uang dan lapangan kerja lebih banyak di perkotaan daripada di daerah asal PRT. Kemiskinan yang dihadapi PRT juga dihadapi anggota keluarga PRT lainnya yang umumnya bekerja di sektor pekerja kasar yang berupah rendah. Sementara itu, para ibu mereka umumnya bekerja mengasuh anak mereka. Kondisi ini mengingatkan kita pada ungkapan "masa depan anak-anak keluarga miskin adalah masa lalu orang tuanya". Hal ini merupakan lingkaran setan atau mungkin evolusi terhadap nasib PRT termasuk PRT anak (PRTA) dan khususnya PRTA perempuan. ${ }^{5}$ Pengalaman kerja PRT yang bekerja sejak usia dini (PRTA) menunjukkan bahwa kemiskinan tidak hanya berdampak pada kapasitas sumberdaya PRTA itu sendiri, akan tetapi juga menyebabkan akses yang lebih kecil pada pekerjaan yang lebih baik. Hal ini bisa dilihat 
misalnya dari pekerjaan PRTA sebelumnya yang hampir sejenis dengan pekerjaan yang mereka lakukan sekarang. 6

Berdasarkan pola rekrutmen yang dialami oleh PRT, terlihat keadaan masyarakat luas yang masih sangat kental pada relasi kekerabatan. Pola rekrutmen seperti ini sangat rawan menjadi korban perdagangan (trafiking). Fakta bahwa PRT diberi informasi, penjelasan dan diajak oleh saudara atau teman sekampung, memperlihatkan budaya asal para PRT yang masih kental dengan "sentimen of community" dan "sentimen of lokality". Kedua hal ini menggambarkan ikatan emosional dan personal yang kuat antara PRT dengan kerabatnya. Hal ini disebabkan oleh perasaan bersama tentang identitas kelompok sosial dan kecintaan terhadap lokasi geografis/desa mereka. Pola relasi seperti itu tampak lebih mengedepan daripada pola relasi kontraktual yang dikembangkan oleh agen penyalur tenaga PRT.

\section{Kondisi Kesehatan Kerja}

Permasalahan kesehatan kerja bagi PRT memerlukan perhatian khusus. Hal ini disebabkan oleh masih banyak permasalahan kesehatan kerja dikalangan PRT, baik secara fisik maupun psikis.Untuk itu, ada beberapa hal yang perlu diperhatikan antara lain: hak perlindungan dan jaminan kesehatan kerja PRT hak memperoleh informasi, otoritas diri, serta pelayanan dan perawatan kesehatan. Selain itu, kesehatan reproduksi juga merupakan isu penting yang perlu mendapat perhatian khusus, terutama karena sebagian besar PRT adalah perempuan. Karena kasus-kasus pelecehan dan kekerasan seksual (KDRT) seringkali ditemukan pada PRT. Menurut informan dari Kelompok Perempuan Pro Demokrasi (KPPD), pelanggaran perburuhan dan kekerasan yang terjadi di sektor PRT, biasanya disebabkan oleh pemahaman yang kurang tentang peraturan perundang-undangan PRT di masyarakat. Selain itu, sebagian dari perlakuan yang tidak pantas tersebut merupakan wujud dari sikap diskriminatif terhadap PRT. Diskriminasi ini didasarkan pada suku, gender, dan kondisi sosial ekonomi.

PRT sering datang dari kelompok etnis yang berbeda dengan majikan mereka, dengan warna kulit, bahasa, praktek-praktek budaya yang berbeda, dan pada beberapa kasus dari agama yang berbeda. Kebanyakan PRT juga merupakan perempuan yang berdasarkan budaya di masyarakat diharapkan menempati posisi yang lebih rendah didalam rumah tangga dan masyarakat. Kesenjangan status sosial dan ekonomi yang ditemukan antara majikan dan PRT juga mempengaruhi sikap majikan terhadap PRT. Sehingga PRT sering kali mendapat perlakuan yang semena-mena dalam pekerjaannya, tumbuh rasa percaya diri yang rendah, sehingga membuat mereka tidak segera meninggalkan majikan yang sewenang- wenang atau tidak melaporkan pelanggaran atas hak-hak mereka. Selain itu, hubungan majikan-pekerja yang bersifat pribadi, dapat berkontribusi pada tingkat ketegangan yang tinggi antara majikan dengan PRT daripada pekerja profesional yang tidak memperlihatkan keterikatan yang lebih besar antara majikan dan pekerja. Di kantor atau pabrik, pekerja tidak menempati ruang pribadi majikan, tidak melibatkan kebutuhan pribadi majikan dan tidak ada pengawasan situasi oleh staf lain yang lebih besar.

Berdasar hasil penelitian Anti-Slavery, ${ }^{7}$ PRT perempuan yang umumnya memasuki sebuah rumah tangga untuk bekerja merupakan anggota dengan yang terendah, subyek untuk diperintah bukan hanya oleh seorang majikan saja tapi juga dari seluruh anggota rumah tangga majikan. Rasio majikan-pekerja yang tidak lazim tersebut, cenderung menjadi norma dalam situasi PRT. Dalam banyak kasus, PRT merupakan satu-satunya pekerja di suatu rumah majikan. Pengisolasian ini memperparah kerentanannya, terutama bila seluruh jalur komunikasi dengan dunia luar, melalui telpon, pos atau interaksi ditiadakan. ${ }^{7}$

Upah dan beban kerja yang diterima PRT menjadi konsekuensi dari pilihan dan keputusannya untuk bekerja sebagai PRT. Dari sisi beban kerja, tampak bahwa pekerjaan yang dilakukan PRT tidak memerlukan keterampilan tinggi meskipun tingkat variasinya banyak. Bahkan ada beberapa PRT yang mengerjakan pekerjaan merawat binatang, mengurus rumah tangga, mengurus pekerjaan dapur, hingga menjadi pekerja kasar di kantor dan menjaga keamanan rumah. Dari sisi waktu, meskipun banyak yang memiliki waktu istirahat, tetapi jam kerja mereka umumnya sangat panjang. Mereka mulai bekerja pada pagi/dini hari hingga malam hari. Fakta ini menggambarkan betapa tidak jelasnya posisi PRT dihadapan undang-undang ketenagakerjaan yang tersedia. Posisi PRT yang tidak jelas ini disebabkan oleh status mereka tidak termasuk dalam kategori buruh, bukan sebagai budak, dan tidak bisa disebut sebagai anggota keluarga. Mereka tidak dapat dinyatakan sebagai buruh karena tidak termasuk dalam undang-undang ketenagakerjaan. Mereka juga tidak bisa disebut sebagai budak, karena PRT dibayar dan tidak sepenuhnya diperhamba. Sedangkan sebagai anggota keluarga pun bukan, karena PRT bukan sanak, bukan kerabat, mereka adalah orang asing yang ikut sementara.

Namun, pada kenyataanya posisi PRT telah mengintegrasikan seluruh kemiripan yang ada antara semua sisi buruk dari ketiga status tersebut diatas. Fakta tentang kapasitas kerja, beban kerja, dan beban tambahan yang diterima PRT mengharuskan kita untuk merumuskan pengertian PRT sebagai "pekerja yang serba bukan" karena posisi "marginal" dari status sekaligus posisi PRT. Dalam status dan posisi seperti ini, keberadaan 
anak dibawah umur yang bekerja sebagai PRT, mengharuskan diri mereka menerima beban lebih berat daripada majikan mereka yang telah dewasa. Hal ini bukan saja karena kehilangan waktu bermain, tetapi juga karena status yang tidak pasti itu membawa tekanan berlebih akibat tuntutan majikan, tidak adanya perlindungan hukum dan kesehatan serta hilangnya kasih sayang akibat hidup dalam "pseudo family". Dari sisi hak asasi sosial, ekonomi dan budaya, semua yang dialami oleh PRTA juga merupakan bentuk kekerasan kontinum yang dalam periode tertentu bisa terakumulasi dalam wujud kekerasan fisik yang bisa mengakibatkan cacat seumur hidup atau bahkan kematian. ${ }^{8}$ Keterbatasan akses PRT terhadap informasi, menyebabkan kesulitan bagi PRT untuk memperoleh informasi tentang upaya-upaya mengembangkan organisasi yang bisa memperjuangkan hak-hak mereka sebagai perempuan, pekerja, dan warga negara.

\section{Kebijakan Pemerintah}

Perlindungan hukum bagi PRT di Surabaya yang sampai saat ini belum tersedia mencerminkan bahwa PRT masih belum dianggap sebagai profesi yang layak diatur secara khusus sebagaimana layaknya profesi-profesi lainnya. Dengan demikian, hubungan kerja yang bersifaf informal dan kekerabatan lebih dikedepankan. Padahal, sebagai pekerja, PRT harus dilindungi oleh hukum, peraturan dan keputusan yang ada dalam rangka mewujudkan konsidi kerja yang layak sebagaimana yang tercantum dalam konvensi ILO. Tanpa perlindungan (intervensi yuridis), maka PRT tidak juga mendapat perlindungan dari dimensi sosial, termasuk kontrol sosial dari masyarakat. Akibatnya, kasus kekerasan terhadap PRT sering terjadi di rumah-rumah yang dikelilingi oleh pagar tembok besar. Sehingga kontrol sosial sulit dilakukan dan masyarakat sering tidak tahu apa yang terjadi di dalam rumah tangga. Selain itu, anggapan bahwa sektor domestik sebagai sektor privat juga membuat orang/ masyarakat tidak berani melakukan tindakan pencegahan atau intervensi, meskipun mereka mengetahui ada gejala-gejala yang mencurigakan. ${ }^{4}$

\section{Kesimpulan}

Berbagai masalah struktural seperti kemiskinan, diskriminasi, ideologi patriarki, feodalisme dan kelas menyelimuti keberadaan PRT. Selain itu, persoalan mengenai perlindungan sosial bagi PRT dan sanksi hukum bagi para pengguna jasa yang melakukan penyiksaan terhadap PRT. Masalah-masalah yang dihadapi PRT ketika bekerja antara lain adalah usia sangat muda, waktu kerja panjang, upah rendah, tidak ada jaminan kesehatan, tidak ada pengakuan dan penghargaan sebagai pekerja, wilayah kerja rumah tangga yang bersifat pribadi, eksploitasi oleh agen penyalur tenaga kerja, eksploitasi oleh pengguna jasa, rentan diperdagangkan, tidak punya akses terhadap informasi dan pendidikan. Hak perlindungan dan jaminan kesehatan kerja PRT untuk memperoleh informasi, otoritas diri, serta pelayanan dan perawatan kesehatan masih belum terpenuhi. Kesehatan reproduksi merupakan isu yang penting yang perlu diperhatikan, terutama karena sebagian besar PRT adalah perempuan. Selain itu, sejumlah kasus pelecehan dan kekerasan seksual (KDRT) seringkali dihadapi oleh PRT. Upah dan beban kerja yang diterima PRT menjadi konsekuensi dari pilihan dan keputusannya untuk bekerja sebagai PRT. Meskipun dari sisi beban kerja, tampak bahwa pekerjaan yang dilakukan PRT tidak memerlukan keterampilan tinggi dengan tingkat variasi yang banyak. Fakta tentang kapasitas kerja, beban kerja, dan beban tambahan yang diterima PRT menjadikan PRT sebagai "pekerja yang serba bukan" karena posisi "marginal" dari status sekaligus posisi PRT. Namun, sampai saat ini belum ada perlindungan hukum dan organisasi bagi para PRT yang berfungsi sebagai wadah untuk menyalurkan hak-hak mereka sebagai perempuan, pekerja, dan warga negara.

\section{Saran}

Perlu perhatian khusus Pemerintah (khususnya Pemerintah Daerah Provinsi Surabaya) terhadap profesi PRT, mengingat profesi PRT sebagai sektor domestik dengan kemampuan ketrampilan pekerjanya yang rendah sering mengalami perlakuan yang tidak adil dari majikannya dan kekerasan dalam rumah tangga. Perlu ada perlindungan kesehatan kerja PRT termasuk perlindungan hak mereka untuk berorganisasi. Hal ini harus menjadi salah satu agenda utama dalam pembuatan kebijakan Pemerintah Daerah Surabaya. Untuk itu, perlu ada perlindungan hukum yang tidak hanya pro majikan, sehingga dapat melindungi hak, kepentingan dan kebutuhan PRT. PRT perlu mendapat kesempatan yang luas untuk mengikuti berbagai pendidikan dan pelatihan, sehingga dapat menjadi bekal dalam meningkatkan kemampuan dan ketrampilan PRT dalam menjalani kehidupan masa depan yang lebih baik. Perlu ada pendataan dan penelitian lebih lanjut Tentangi keberadaan PRT di Surabaya, mengingat belum adan data resmi yang menjelaskan tentang jumlah PRT di Surabaya.

\section{Daftar Pustaka}

1. Kompas, 15 Mei 2006

2. Komnas Perempuan, Draft Policy Document untuk Perlindungan Pekerja Rumah Tangga. Jakarta. 2003.

3. Depkes. Upaya Kesehatan Kerja Sektor Informal di Indonesia. Jakarta. 1993.

4. Badan Pemberdayaan Masyarakat Propinsi Jawa Timur. Domestic Workers Legal Study. Surabaya. 2006. 
5. Lembaga Bantuan Hukum Perempuan Indonesia (LBH APIK). Kertas Posisi Usulan Revisi Perda DKI Jakarta No. 6 tahun 1993 tentang Pramuwisma. Jakarta 2002.

6. Menteri Negara Pemberdayaan Perempuan. Panduan Kebijakan Perlindungan Pekerja Rumah Tangga Anak. Jakarta. 2004.
7. Anti-Slavery. Discussion paper on the Protection of Domestic workwers. Jakarta. 2003.

8. Menteri Negara Pemberdayaan Perempuan. Panduan Kebijakan Perlindungan Pekerja Rumah Tangga Anak. Jakarta. 2004. 